\title{
Design Procedure for Compact Folded Waveguide Filters
}

\author{
Dong, Yunfeng; Johansen, Tom Keinicke; Zhurbenko, Vitaliy; Acar, Öncel
}

Link to article, DOI:

10.1109/URSI-AT-RASC.2015.7302848

Publication date:

2015

Document Version

Publisher's PDF, also known as Version of record

Link back to DTU Orbit

Citation (APA):

Dong, Y., Johansen, T. K., Zhurbenko, V., \& Acar, Ö. (2015). Design Procedure for Compact Folded Waveguide Filters. Abstract from 1st URSI Atlantic Radio Science Conference, Gran Canaria, Spain.

https://doi.org/10.1109/URSI-AT-RASC.2015.7302848

\section{General rights}

Copyright and moral rights for the publications made accessible in the public portal are retained by the authors and/or other copyright owners and it is a condition of accessing publications that users recognise and abide by the legal requirements associated with these rights.

- Users may download and print one copy of any publication from the public portal for the purpose of private study or research.

- You may not further distribute the material or use it for any profit-making activity or commercial gain

- You may freely distribute the URL identifying the publication in the public portal

If you believe that this document breaches copyright please contact us providing details, and we will remove access to the work immediately and investigate your claim. 


\title{
Design Procedure for Compact Folded Waveguide Filters
}

\author{
Yunfeng Dong ${ }^{(1)}$, Tom K. Johansen ${ }^{(1)}$, Vitaliy Zhurbenko ${ }^{(1)}$, Öncel Acar ${ }^{(1)(2)}$ \\ (1) Department of Electrical Engineering, Technical University of Denmark, \\ 2800 Kgs. Lyngby, Denmark \\ (2) MTI Radiocomp, Krakasvej 17, 3400 Hillerød, Denmark
}

\begin{abstract}
Waveguide filters are widely used in communication systems due to low losses and high power handling capabilities. One drawback of the conventional waveguide filters is their large size, especially for low-frequency and high-order realizations. It has been shown that the footprint of conventional waveguide resonators can be reduced to one quarter by folding the electric and magnetic fields inside the cavity (J. S. Hong, Microwave Symposium Digest, 2004, Vol. 1, pp. 213-216).
\end{abstract}

This paper presents a novel systematic procedure for designing compact low-loss bandpass filters by using folded waveguide resonators. As a design example, a scaled version of a filter specified for a TETRA (Terrestrial Trunked Radio) system has been considered. The folded waveguide filter is designed to fulfil specific requirements, and the design procedure can be easily applied to other folded waveguide filter designs. The insertion loss in the pass-band $(1.54 \mathrm{GHz}-1.56 \mathrm{GHz})$ is specified to be less than $1 \mathrm{~dB}$ while the return loss should be more than $18 \mathrm{~dB}$. The isolation in the rejection-band $(1.58 \mathrm{GHz}-1.60 \mathrm{GHz})$ is required to be more than $45 \mathrm{~dB}$. The coupling matrix synthesis is introduced first and a two-layer realization structure is proposed with about $87.5 \%$ reduction of the footprint compared to a conventional waveguide filter design. After that, a step-by-step description of the design procedure that meets the specific requirements is given. The designed folded waveguide structure is modelled and verified by three-dimensional full-wave electromagnetic simulations. The proposed structure and the fabricated folded waveguide filter are shown in Fig. 1.

A network analyzer (HP8720D) was used to test the fabricated folded waveguide filter. The measurement results are shown in Fig. 2 in comparison with the simulation results. A good agreement between the simulation and measurement validates the described design procedure.
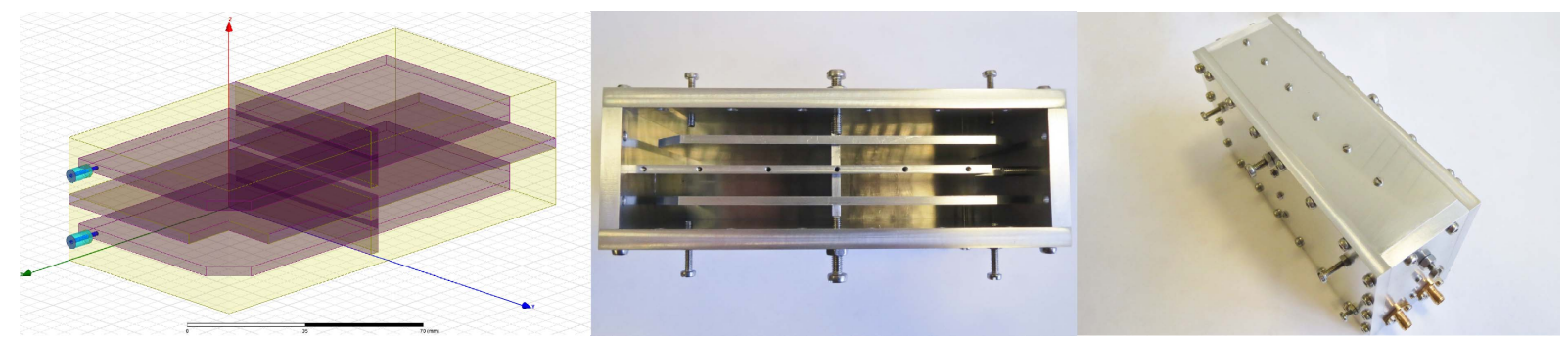

Fig. 1. Proposed structure and fabricated folded waveguide filter.

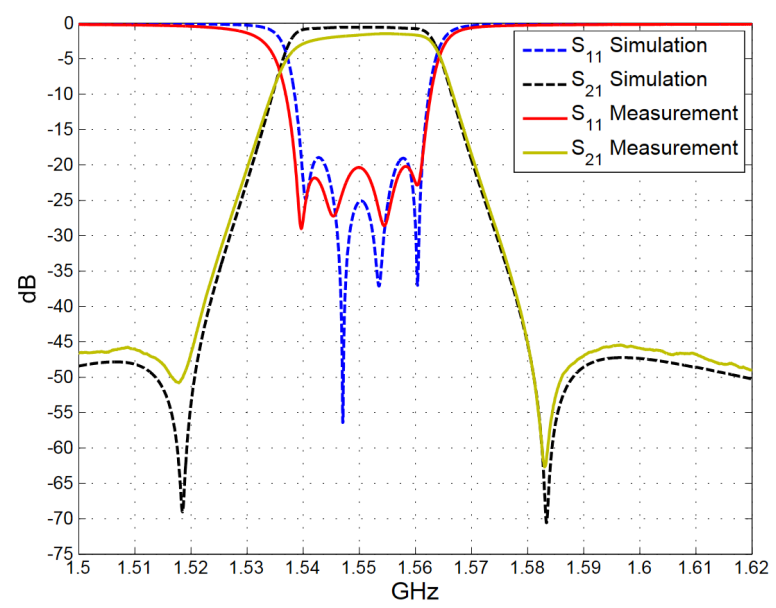

Fig. 2. Simulation and measurement results of the designed folded waveguide filter. 